\title{
ПОНЯТТЯ АДМІНІСТРАТИВНОЇ ЮРИСДИКЦІї В ПАРАДИГМІ ПРАВОВОЇ ДЕРЖАВИ
}

\section{THE CONCEPT OF ADMINISTRATIVE JURISDICTION UNDER THE FRAMEWORK OF THE STATE OF LAW}

Вовк П.В., к.ю.н., докторант

Науково-дослідний інститут публічного права

\begin{abstract}
Мета статті полягає в тому, щоб на основі філософії права, теорії адміністративного права і процесу, норм законодавства сфоормувати поняття адміністративної юрисдикції в парадигмі правової держави. У статті проаналізовано наукові підходи до визначення поняття «адміністративна юрисдикція». Визначено, що адміністративна юрисдикція в парадигмі правової держави є складним правовим процесуальним інститутом, метою якого $€$ не лише захист прав осіб, але також і їх відновлення. Сформовано поняття адміністративної юрисдикції в парадигмі правової держави як визначеної законодавством компетенції уповноважених органів влади щодо розгляду та вирішення адміністративних справ, притягнення винних осіб до адміністративної відповідальності та використання інших повноважень щодо вирішення різних публічно-правових питань в межах адміністративного спору. З'ясовано, що у більшості випадків адміністративна юрисдикція ототожнюється з діяльністю щодо розгляду справ про адміністративні правопорушення та винесенню відповідних постанов у встановлених законом формах, або як врегульована законом діяльність уповноваженого органу, посадової особи щодо розгляду справ про адміністративні правопорушення та застосування заходів адміністративної відповідальності - адміністративних стягнень. Більш широкий підхід щодо розуміння суті адміністративної юрисдикції включає вирішення питань, які виникають у специфічний сфері взаємних правовідносин між державою і громадянином, передусім у сфері здійснення державної виконавчої влади. Зроблено висновок, що адміністративна юрисдикція в парадигмі правової держави - це визначена законодавством компетенція уповноважених органів влади щодо розгляду та вирішення адміністративних справ, притягнення винних осіб до адміністративної відповідальності та використання інших повноважень щодо вирішення різних публічно-правових питань в межах адміністративного спору з метою здійснення справедливого адміністративного судочинства, захисту та відновлення прав, свобод та законних інтересів осіб, суспільства та держави, реалізації функцій правової держави.
\end{abstract}

Ключові слова: адміністративне судочинство, адміністративний процес, адміністративні суди, захист прав і свобод, парадигма, правова держава, принцип верховенства права, суб'єкти владних повноважень, теорія адміністративного судочинства.

The purpose of the article is to form the concept of administrative jurisdiction in the paradigm of the rule of law on the basis of philosophy of law, theory of administrative law and process, norms of legislation. The article identifies scientific approaches to the definition of "administrative jurisdiction". It is determined that administrative jurisdiction in the paradigm of the rule of law is a complex legal procedural institution, the purpose of which is not only to protect the rights of individuals, but also to restore them. Formed concept of administrative jurisdiction in the paradigm of law as defined by law jurisdiction competent authorities to consider and resolve administrative cases, bring perpetrators to administrative responsibility and use other powers to resolve various public law issues within an administrative dispute. It was found that in most cases administrative jurisdiction is identified with the activity of considering cases of administrative offenses and making relevant decisions in the forms prescribed by law, or as regulated by law the activities of the authorized body, official to consider cases of administrative offenses - application of administrative liability administrative penalties. A broader approach to understanding the essence of administrative jurisdiction includes resolving issues that arise in the specific field of mutual legal relations between the state and the citizen, especially in the exercise of state executive power. It is concluded that administrative jurisdiction in the paradigm of the rule of law is the statutory competence of authorized authorities to consider and resolve administrative cases, bring perpetrators to administrative responsibility and use other powers to resolve various public law issues within an administrative dispute in order to implement a fair administrative proceedings, protection and restoration of rights, freedoms and legitimate interests of individuals, society and the state, the implementation of the functions of the rule of law.

Key words: administrative courts, administrative justice, administrative process, constitutional state, paradigm, protection of rights and freedoms, subjects of authority, rule of law, theory of administrative justice.

Актуальність теми. В сучасних умовах проблеми адміністративної юрисдикції залишаються не досить розробленими. Так, відсутній єдиний підхід вчених-правників до визначення адміністративної юрисдикції, яка доволі спрощено ототожнюється з підвідомчістю, що видається спірним. 3 практичної точки зору дослідження адміністративної юрисдикції зумовлено неоднозначним вирішенням питання про належність того чи іншого спору або іншого правового питання до відання конкретного суду, що в кінцевому підсумку призводить до порушення права людини на справедливий розгляд його справи упродовж розумного строку незалежним і безстороннім судом, встановленим законом. Усе це зумовлює актуальність даного дослідження [7, с. 40].

Таким чином, враховуючи відсутність єдиного підходу до поняття адміністративної юрисдикції, сучасне розуміння цієї правової категорії в парадигмі правової держави вимагає комплексного наукового дослідження.

Стан дослідження. До наукової проблеми сутності адміністративної юрисдикції звертали свою увагу чисельні вітчизняні вчені-адміністративісти, серед них: В. Авер'янов, О. Бандурка, О. Бачеріков, В. Бевзенко, В. Галунько, Л. Глущенко, О. Дубенко, А. Івани- щук, В. Кравчук, О. Кузьменко, Р. Кузьмін, О. Міщенко, С. Потапенко, А. Руденко, Я. Рябченко, М. Сорока, С. Стеценко, О. Умнова, Е. Швед, Н. Шевцова, О. Яцун та ін. Проте, в парадигмі сучасної правової держави наукова категорія «адміністративної юрисдикції» вимагає нового наукового погляду.

Мета статті полягає в тому, щоб на основі філософії права, теорії адміністративного права і процесу, норм законодавства сформувати поняття адміністративної юрисдикції в парадигмі правової держави.

Викладення основних положень. Згідно 3 поширеним визначенням адміністративна юрисдикція (від латинського «юрис» - право, «дико» - кажу) - це встановлена законом чи іншим нормативним актом сукупність правових повноважень відповідних державних органів вирішувати правові спори, в тому числі вирішувати справи про правопорушення, тобто оцінювати дії особи чи іншого об'єкта права 3 точки зору їх правомірності, застосовувати юридичні санкції до правопорушників [9, с. 16].

Нині відсутній однозначний підхід до суб'єктного складу адміністративної юрисдикції. Проте, з урахуванням чинного законодавства правильнішою видається точка зору, згідно з якою в якості суб'єкта адміністративної 
юрисдикції слід визнавати не лише органи виконавчої влади (посадові особи), але й органи судової влади $[2$, c. $76-80]$

В адміністративно-правовій науці, як проаналізував вчений О. Іщук, склалося декілька точок зору щодо визначення суті, змісту й обсягу адміністративної юрисдикції. У більшості випадків адміністративна юрисдикція ототожнюється 3 діяльністю щодо розгляду справ про адміністративні правопорушення та винесенню відповідних постанов у встановлених законом формах, або як врегульована законом діяльність уповноваженого органу, посадової особи щодо розгляду справ про адміністративні правопорушення та застосування заходів адміністративної відповідальності - адміністративних стягнень. Таке розуміння досліджуваного явища відображає звужений підхід Більш широкий підхід щодо розуміння суті адміністративної юрисдикції включає вирішення питань, які виникають у специфічний сфері взаємних правовідносин між державою і громадянином, передусім у сфері здійснення державної виконавчої влади. У широкому розумінні адміністративна юрисдикція розглядається як врегульована законом діяльність уповноваженого органу державної влади, посадової особи щодо вирішення індивідуальних адміністративних справ (спорів), пов'язаних з адміністративно-правовими відносинами громадянина або недержавної організації з державним органом (його посадовою особою) при здійсненні цим органом публічної влади, як правило, виконавчої влади. Така позиція прихильників широкого розуміння адміністративної юрисдикції відображає здійснення юрисдикційної діяльності до меж розгляду будь-якого публічно-правового спору, включаючи й адміністративні суди [4, с. 419-424].

Ми підтримуємо вищевказану позицію, та вказуємо, що адміністративна юрисдикція в парадигмі правової держави $є$ складним правовим процесуальним інститутом, метою якого $є$ не лише захист прав осіб, але також і їх відновлення.

У юридичній літературі, як визначив Я. Сідей, сформувалися три основні тенденції в розумінні адміністративної юстиції, яку розглядають як: 1) особливий порядок вирішення адміністративно-правових спорів судами та уповноваженими на те державними органами (згідно 3 цим підходом до поняття адміністративної юстиції включається розгляд публічно-правових спорів не тільки судами, а й іншими державними органами. Можна дійти висновку, що в цьому разі наголос зроблено на розумінні терміна «justitia» як «справедливості». Іншими словами, справедливість під час вирішення спорів може бути забезпечена не лише судами, а й адміністративними органами під час розгляду скарг громадян у сфері адміністративної діяльності); 2) самостійна галузь правосуддя, метою якої є вирішення судами спорів між громадянами та органами управління (адміністрацією) або між самими органами управління, тобто адміністративне судочинство (такий підхід є більш вузьким: до поняття адміністративної юстиції віднесено тільки судовий порядок вирішення публічно-правових спорів, тобто адміністративна юстиція є діяльністю виключно судовою. У такому розумінні наголос зроблено на розумінні терміна «justitia» як «правосуддя», яке відповідно до положень сучасної правової доктрини здійснюється виключно судами); 3) не тільки особливий вид судочинства, а й система спеціалізованих судів або спеціальних судових підрозділів, які здійснюють адміністративне судочинство (згідно 3 цим підходом адміністративною юстицією $\epsilon$ не будьяке вирішення публічно-правових спорів, а тільки те, що здійснюється спеціально утвореними для цього судовими органами - окремими судами чи спеціалізованими структурними підрозділами загальних судів, тобто обов'язковою ознакою адміністративної юстиції $\epsilon$ наявність у судовій системі адміністративних судів або адміністративних палат у структурі судів загальної юрисдикції) [7, с. 40-43].
Е. Демський трактує адміністративну юрисдикцію як встановлену чинним законодавством компетентність (сукупність повноважень) органів публічної адміністрації (посадових осіб) здійснювати свої функції у сфері публічного управління і розглядати будь-які адміністративні справи у відповідній, визначеній адміністративними актами, адміністративно-процесуальній формі, виносити по них рішення із застосуванням у необхідних випадках заходів адміністративного примусу [3, с. 138-139]. В свою чергу, адміністративну юрисдикцію А. Апаров визначив як процесуальну діяльність компетентних органів влади (суб'єктів адміністративної юрисдикції), що здійснюється в установленому порядку (судовому або позасудовому), 3 метою розгляду і вирішення адміністративно-правового конфлікту, який може виступати у двох правових формах: адміністративно-правовий спір; адміністративне правопорушення [2, с. 76-80].

Адміністративна юрисдикція, з позиції О. Чернобай, це діяльність щодо розгляду адміністративних публічних спорів і вирішення справ про адміністративні правопорушення, що здійснюється уповноваженими на те державними органами, а також діяльність по застосуванню до винних осіб заходів примусового характеру. Отже, адміністративна юрисдикційна діяльність $є$ досить важливою для всієї системи державного управління, адже вона спрямована на забезпечення та належний захист основних прав та свобод людини і громадянина, захист суспільних відносин, що складаються у сфері державного управління, активізацію боротьби 3 найбільш чисельною різновидністю правопорушень, якими $є$ адміністративні правопорушення [8, с. 82-88].

Професор В. Б. Авер'янов вказував, що зміст інституту «адміністративна юрисдикція» необхідно юридично закріпити у відповідному нормативно-правовому акті, відповідно у ньому об'єднати юрисдикційну діяльність: a) органів виконавчої влади, уповноважених розглядати скарги громадян і юридичних осіб на незаконно прийняті рішення, як нижчих органів, так і підлеглих осіб, тобто сфера адміністративного оскарження (адміністративна «квазіюстиція»); б) органів виконавчої влади, уповноважених застосовувати заходи адміністративної відповідальності (адміністративна позасудова юстиція); в) адміністративних судів (адміністративна судова юстиція) [1, с. 193-195].

Як вказує А. Апаров, у концептуальному плані питання про предмет адміністративної юрисдикції є одним із найбільш дискусійних в сучасний період. У зв'язку з цим можна виділити два напрями: 1) предметом адміністративної юрисдикції виступає або спір про право, або адміністративне правопорушення; 2) предметом адміністративної юрисдикції $є$ не лише адміністративні спори, але і застосування заходів примусу, а також відновлення порушеного права. Вчений пов'язує поняття «адміністративна юрисдикція» 3 певного роду або виду виконавчо-розпорядчою діяльністю 3 вирішення індивідуальних справ, що $є$ спорами у сфері державного управління. Ця діяльність здійснюється шляхом реалізації відповідних правових норм і вимог за допомогою заходів позасудового (адміністративного примусу). Юрисдикція має місце тоді, коли слід вирішити спір про право. При цьому, науковець не зводить юрисдикцію тільки до вирішення спорів про право, але і звертаємо увагу на те, що юрисдикція може бути діями органів влади, які виступають спеціальними органами каральної адміністративної юрисдикції. Нарешті, «під адміністративну юрисдикцію в широкому значенні слова підпадають і конкретні випадки розгляду органами управління питань про права і обов'язки або правові інтереси фізичних і юридичних осіб [2, с. 76-80].

O. I. Чернобай цілком точно, як науковець, виділив певні ознаки адміністративної юрисдикції: 1) є складовою частиною виконавчо-розпорядчої діяльності відповідних 
органів державної влади; 2) підставою є наявність правопорушення (правового конфлікту). Тобто, початком здійснення адміністративно-правової юрисдикції $\epsilon$ наявність відповідного спору, що виникає між сторонами адміністративної діяльності та потребує свого вирішення, а також під час вчинення адміністративного правопорушення. У свою чергу, варто зазначити, що розгляд і рішення юридичних справ, обумовлених позитивними обставинами, не охоплюються юрисдикційною діяльністю. Юрисдикція виникає лише тоді, коли необхідно вирішити суперечку про право, порушення встановлених правових норм; 3) адміністративна юрисдикція носить державно-владний характер, оскільки одним із учасників цих правовідносин обов'язково виступає орган державної влади, а тому і відносини, що виникають носять державно-владний характер; 4) розгляд спорів, що відносяться до адміністративної юрисдикції здійснюються виключно уповноваженими на те державними органами та судом. Тобто, законодавством чітко встановлюється перелік державних органів, які здійснюють розгляд певних категорій справ. Розгляд справ іншими органами, ніж ті, що передбачені законом не допускається; 5) наявність законодавчо регламентованої процесуальної форми здійснення адміністративної юрисдикції. Тобто, процедура розгляду правового спору між учасниками здійснюється не в довільній формі, а у чітко регламентованій законом процесуальній формі; 6) участь самих сторін конфлікту в процесі його вирішення. Тобто сторони беруть безпосередню участь у розгляді правового конфлікту, шляхом надання пояснень, доказів тощо;
7) інстанційність оскарження дій, бездіяльності і рішень органів, які наділені адміністративною юрисдикцією. Це означає, що звернення особи до відповідного органу державної влади не позбавляє права на звернення цієї особи до вищестоящого органу чи до суду; 8) індивідуальність розгляду кожного правового спору; 9) розгляд правового спору закінчується прийняттям відповідного процесуального рішення, яке врегульовує конкретне питання по суті конфлікту. Таке рішення може містити і певні санкції для однієї чи обох сторін конфлікту; 10) застосування заходів державного примусу, які необхідні для виконання вищезазначеного рішення у повному обсязі. Тобто, у випадку невиконання рішення, прийнятого по правовому спору уповноважені на те органи мають право застосовувати примусові заходи для його виконання [8, с. 82-88].

Висновки. Таким чином, аналізуючи наукові підходи, ще раз можна підкреслити про відсутність єдиного підходу до визначення поняття «адміністративна юрисдикція».

На наш погляд, адміністративна юрисдикція в парадигмі правової держави - це визначена законодавством компетенція уповноважених органів влади щодо розгляду та вирішення адміністративних справ, притягнення винних осіб до адміністративної відповідальності та використання інших повноважень щодо вирішення різних публічно-правових питань в межах адміністративного спору з метою здійснення справедливого адміністративного судочинства, захисту та відновлення прав, свобод та законних інтересів осіб, суспільства та держави, реалізації функцій правової держави.

\section{ЛITEPATYPA}

1. Авер'янов В. Б. Питання адміністративної реформи у змісті Загальної концепції державно-правової рефрорми. Державно-правова реформа в Україні : тези матеріалів наук.-практ. конф. Київ, 1997. С. 193-195.

2. Апаров А. М. Поняття і особливості адміністративної юрисдикції. Європейські перспективи. 2013. № 10. С. $76-80$.

3. Демський Е. Ф. Адміністративне процесуальне право України: навчальний посібник. К. : Юрінком Інтер, 2008. 496 с.

4. Іщук О. С. Поняття адміністративної юрисдикції: проблеми дефрініції. Форум права. 2011. № 1. С. 419-424.

5. Кодекс адміністративного судочинства України. Відомості Верховної Ради України. 2005. № 35-36, № 37. Ст. 446.

6. Практика Конституційного Суду з питань діяльності органів адміністративної юрисдикції. Конституційний Суд: офіційний веб-сайт. 2017. ULR: http://ccu.gov.ua/storinka-knygy/5513-organy-administratyvnoyi-yurysdykciyi.

7. Сідей Я. Я Розмежування адміністративної юрисдикції з іншими видами юрисдикції у сфері судової компетенції. Підприємництво, господарство і право. 2018. № 6. С. 40-43.

8. Чернобай О. І. Теоретичні узагальнення щодо розуміння сутності поняття «адміністративна юрисдикція». Науковий вісник Академії муніципального управління. Серія : Право. 2015. Вип. 1(2). С. 82-88.

9. Юридический энциклопедический словарь / гл. ред. А. Я. Сухарева. Москва: Советская энциклопедия, 1984. 415 с. 